\title{
Directionality of Pollinator Movements in Watermelon Plantings
}

\author{
S. Alan Walters ${ }^{1}$ \\ Department of Plant, Soil, and Agricultural Systems, Southern Illinois \\ University, 1205 Lincoln Drive, Room 176 Ag. Building, Carbondale, IL \\ 62901-4415
}

Jonathan R. Schultheis

Department of Horticultural Science, North Carolina State University, Raleigh, NC 27695-7616

Additional index words. Apis mellifera, Citrullus lanatus, gene flow, pollen flow

\begin{abstract}
Insect pollinators such as honeybees (Apis mellifera L.) and bumble bees (Bombus spp.) are strongly directional in their movements among flowers and typically move to the nearest neighboring inflorescence, which is often in the same row. Pollinator movements in watermelon [Citrullus lanatus (Thunb.) Matsum \& Nakai] were determined by tracking pollen flow with the incompletely dominant lobed-leaf trait of 'Crimson Sweet' ( $\mathrm{Nl})$ as the pollen donor and the incompletely recessive 'Sunshade' $(n l)$ as the recipient. Mature 'Sunshade' watermelon fruit were collected at 3-m increments down selected rows and across all rows in both directions from the central donor plants that made up $1 \%$ of the planting. The resulting progenies from each fruit collected were screened to determine the directionality of pollinator movements by the occurrence of the $N I n l$ genotype (or lobed-leaf phenotype). The row that went through the central donor plant block had higher percentages of lobed-leaf seedlings compared with the other rows evaluated. However, lobed-leaf seedlings were observed on rows at significant distances (greater than $10 \mathrm{~m}$ ) from the donor block. This resulted most likely from long-distance pollen transport, in-hive pollen transfer, or multiple transfers of pollen to staminate (male) and/or pistillate (female) flowers by pollinators before reaching the final destination on a stigmatic surface at a substantial distance from donor plants. Because watermelon vines grow out in all directions, including across rows, a pollinator can easily move to adjacent flowers on a vine growing across rows; thus, the movements of pollinators in watermelon (and most likely other vining cucurbits) are not as simple as maintaining a linear direction down the row.
\end{abstract}

Cucurbit vegetables are predominantly out-crossers and depend on insect pollinators to transfer pollen from staminate to pistillate or hermaphroditic flowers for fruit set and development (Robinson and Decker-Walters, 1997). Although there are many different insect pollinators of cucurbits, honeybees and bumble bees are two of the most important for this group of vegetables (Delaplane and Mayer, 2000; Free, 1993; McGregor, 1976). Honeybees and bumble bees are strongly directional in their movements among flowers and typically move to the nearest neighboring inflorescence, which is often in the same row (Cresswell et al., 1995; Handel, 1982; Levin et al., 1971; Zimmerman, 1979). The maintenance of flight direction (directionality) by bee pollinators, which is the tendency to fly straight ahead from one flower to the next, most likely results in reducing the probability of revisiting flowers and maximizing foraging efficiency (Collevatti et al., 2000).

\footnotetext{
Received for publication 16 June 2008. Accepted for publication 11 Sept. 2008.

${ }^{1}$ To whom reprint requests should be addressed; e-mail awalters@siu.edu
}

The foraging behaviors of insect pollinators play a major role in determining gene flow in plant populations (Collevatti et al., 2000; Handel and Mishkin, 1984; Levin et al., 1971). Pollinator movement among flowers of similar or closely related species is probably one of the most important factors that affect gene flow in plant populations. Gene flow in plants is mediated by both pollen and seed dispersal (Handel, 1982; Waser, 1991); and, in recent years, gene movement has gained additional attention with the release of genetically modified organisms into the environment (Hails, 2000; Hokanson et al., 1997a, 1997b; Manasse, 1992; Rogers and Parkes, 1995; Umbeck et al., 1991).

Although pollinating insects such as honeybees and bumble bees can bring cucurbit pollen from considerable distances to achieve cross-pollination, most studies have generally indicated that the majority of cucurbit pollen movements are somewhat restricted with most pollen carried only a short distance from the source plant. In muskmelon (Cucumis melo L.), Handel (1982) determined that although there was a definite directionality of gene flow, movement tended to be restricted to less than $3 \mathrm{~m}$ from donor plants. In similar studies with cucumber (Cucumis sativus L.), beedispersed pollen was again restricted to 2 to
$3 \mathrm{~m}$ from donor plants, although the gene investigated was found to be clustered on the plot edges of receipt plants (Handel, 1983). Furthermore, Hokanson et al. (1997a) indicated that the greatest amounts of cucumber gene flow occurred at distances closest to donor plants and declined rapidly with increasing distance from the donor plot edge; and, although long-distance gene flow was generally low, increasing the number of donor plants increased both short- and longdistance gene flow. However, Robinson and Decker-Walters (1997) indicated that crosspollination of a wild bitter gourd with cultivated squash (both Cucurbita pepo L.) is possible even in isolated seed production fields because bees can carry pollen for significant distances. Furthermore, Kirkpatrick and Wilson (1988) found reciprocal hybridizations between cultivated Cucurbita pepo and the native Texas gourd (Cucurbita texana Gray) at distances up to $1300 \mathrm{~m}$.

Although several studies have focused on pollen movement of cucurbits, little has been done to place this in the context of pollinator flight patterns and none have determined pollen flow of watermelon. Therefore, a morphologically marked watermelon genotype was used to determine the directionality of pollinator movements down and across rows by tracking pollen flow.

\section{Materials and Methods}

The direction of pollinator movement was determined by tracking watermelon pollen flow by honeybees under field conditions during 2001 and 2002 at the Southern Illinois University Horticultural Research Center in Carbondale. Because pollen readily adheres to insect pollinators such as honeybees, insect-borne pollen is a natural marker that can be used to track insect movements (Silberbauer et al., 2004). The incompletely dominant lobed-leaf trait of 'Crimson Sweet' $(N l)$ was used as the pollen donor and the incompletely recessive nonlobed leaf trait of 'Sunshade' $(n l)$ as the pollen recipient (Mohr, 1953). Because the resulting F1 progeny $(\mathrm{Nlnl})$ produces significant lobing of leaves, the lobed-leaf trait serves as an easy and reliable seedling marker trait. 'Crimson Sweet' and 'Sunshade' are both monoecious, open-pollinated inbreds that have similar flowering and fruiting characteristics. 'Crimson Sweet' seed were obtained from Willhite Seeds (Poolville, TX), whereas seed of 'Sunshade' were donated by Seminis Vegetable Seeds (Oxnard, CA). Both cultivars were self-pollinated with seed increased in the Southern Illinois University Horticultural Research Greenhouse during 2000.

A $900-\mathrm{m}^{2}$ area $(30 \mathrm{~m} \times 30 \mathrm{~m})$ was planted in 'Sunshade' watermelon using 19 rows planted in an east-west direction. Rows were $30 \mathrm{~m}$ long and planted on 1.6- $\mathrm{m}$ centers with plants spaced $1.2 \mathrm{~m}$ apart in the row (25 plants per row) 'Crimson Sweet' was planted in a 9- $\mathrm{m}^{2}(3 \mathrm{~m}$ $\times 3 \mathrm{~m}$ ) area at the midpoint of rows 9,10 , and 11 with three plants in each row (Fig. 1). A mature silver maple (Acer saccharinum L.) 


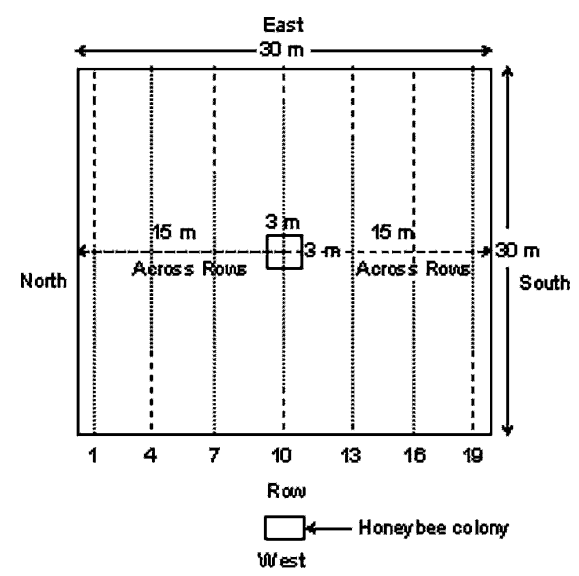

Fig. 1. Field design for pollinator movement study in watermelon during 2001 and 2002. The experiment was $900 \mathrm{~m}^{2}(30 \mathrm{~m} \times 30 \mathrm{~m})$ with the center $3 \mathrm{~m} \times 3-\mathrm{m}$ area planted to 'Crimson Sweet' and the rest planted in 'Sunshade'. Nineteen rows were planted with pollinator movements evaluated down rows 1 (northern most), 4, 7, 10,13, 16, and 19 (southern most) as well as across the rows for $15 \mathrm{~m}$ north and south from the central 'Crimson Sweet' donor block.

grove ( 1 to $2 \mathrm{ha} ; \approx 15 \mathrm{~m}$ in height and located $\approx 10 \mathrm{~m}$ from the test site) was west and southwest of the watermelon planting, which prevented prevailing southwesterly winds from influencing bee flight patterns. Watermelon seeds were directly planted in the field on 20 May each year and thinned to the desired spacing at the two to three true-leaf stage. Standard cultural practices for watermelon in the midwest were used (Foster et al., 2001, 2002). Before watermelon planting, $336 \mathrm{~kg} \cdot \mathrm{ha}^{-1}$ of $13 \mathrm{~N}-13 \mathrm{P}-13 \mathrm{~K}$ fertilizer was broadcast-applied and incorporated into the soil. Approximately 6 weeks later, each row was side-dressed with $52 \mathrm{~kg} \cdot \mathrm{ha}^{-1} \mathrm{~N}$ from $\mathrm{Ca}\left(\mathrm{NO}_{3}\right)_{2}$. Diseases and insects were controlled by spraying recommended rates of esfenvalerate (Asana; E.I. du Pont de Nemours and Co., Wilmington, DE) and chlorothalonil (Bravo; Zeneca, Inc., Wilmington, $\mathrm{DE}$ ) during the early evening at $\approx 10$-d intervals starting at the three to four true-leaf stage. Early setting fruit were removed from 'Sunshade' and 'Crimson Sweet' plants; and, when plants were in full flower, a strong honeybee colony ( $\approx 25,000$ bees) was placed $\approx 10 \mathrm{~m}$ to the west of the test site each year (Fig. 1) with the opening of the hive facing east toward the watermelon field. The most prevalent pollinators were determined five times throughout the peak watermelon flowering period during each year. Bee activity over a 4 -h period $(0700 \mathrm{HR}$ until pollinator activity had stopped at $\approx 1100 \mathrm{HR}$ ) was recorded for randomly selected female and male flowers throughout the watermelon planting. The primary objective for collecting bee foraging data was to determine the pollinator species present. The test site was isolated from other watermelon plantings by at least $2500 \mathrm{~m}$, which should be sufficient based on suggested isolation distances for open-pollinated cucurbit seed production (Maynard and Hochmuth, 1997).

Mature 'Sunshade' watermelon fruit were harvested over a 2 -week period beginning early August during each year. Fruit were harvested in 3-m increments down rows 1,4 , $7,10,13,16$, and 19 and across all 'Sunshade' rows in 3-m increments to the south and north of the central donor 'Crimson Sweet' planting (Fig. 1). Seed were extracted from watermelon fruit and then dried, packaged, and stored for planting.

The $F_{1}$ progeny seed were directly planted into the field at the Southern Illinois University Horticulture Research Center in Carbondale and at the North Carolina State University Cunningham Research Station in Kinston on 20 May during 2002 and 2003 with seed developed from the 2001 and 2002 field experiments, respectively. Seedlings were evaluated at the five to seven leaf stage for the lobed-leaf character. Approximately 60 seeds from each watermelon fruit collected were planted at each location, which provided $\approx 100$ seedlings assessed for the lobed-leaf character from each fruit. A total of $\approx 17,800$ seedlings were evaluated over the 2 years.

The directionality of pollinator movement and pollen flow was determined from the percentage of lobed-leaf seedlings that developed from cross-pollinations of 'Sunshade' with 'Crimson Sweet'. To determine differences in the distribution of lobed-leaf seedlings, Wilcoxon signed rank test analyses were used on paired comparisons of rows using 3-m interval data down the row: 1) north versus south field sections (rows 1 , 4 , and 7 versus 13,16 , and 19); 2) east versus west field sections (all rows 0 to $15 \mathrm{~m}$ and 15 to $30 \mathrm{~m}$ ); and 3 ) east versus west sections for row 10 ( 0 to $15 \mathrm{~m}$ and 15 to $30 \mathrm{~m})$. Also, across-row data were compared using north and south field sections ( 0 to $15 \mathrm{~m}$ north and south from donor plants); and row 10 downthe-row data [0 to $15 \mathrm{~m}$ (west) and 15 to $30 \mathrm{~m}$ (east)] were compared with across-row data (0 to $15 \mathrm{~m}$ north and south from donor plants). Regression analysis was also used to determine the relationship of lobed-leaf seedling percentages with distance from the donor plants.

\section{Results}

Although $\approx 85 \%$ of the pollinators detected were honeybees, other pollinators included bumble bees (Bombus spp.) $(\approx 15 \%)$ and less than $1 \%$ carpenter bees (Xylocopa spp.) and orchard mason bees (Osmia lignaria Say). The pollinators detected were similar over the 2001 and 2002 growing seasons.

Pollen and pollinator movement. Row 10 provided higher percentages of the $N l$ gene $(P$ $\leq 0.05$ ) compared with all other rows based on the Wilcoxon signed rank test (Fig. 2) for data combined over the 2 years. Rows 1,4 , $7,13,16$, and 19 did not differ $(P>0.05)$ for pollen movement. Also, the north-south and east-west field sections based on all row data did not differ for distribution of lobed-leaf

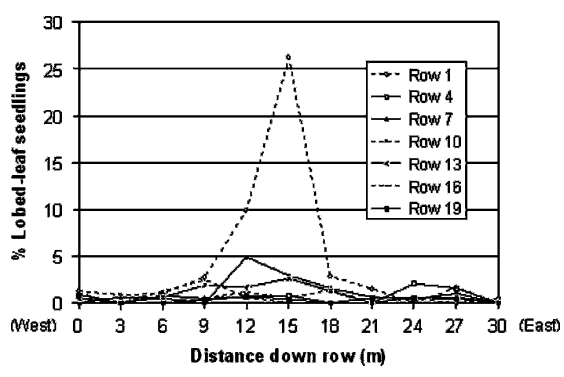

Fig. 2. The percentage of lobed-leaf watermelon seedlings as a function of distance down the row combined for 2001 and 2002. Quadratic models best described pollinator movements (percent lobed-leaf seedlings) both east $(15 \mathrm{~m}$ to $30 \mathrm{~m})$ and west $(15 \mathrm{~m}$ to $0 \mathrm{~m})$ with distance from the center of row 10 that went through the middle of the 'Crimson Sweet' donor plant area. Quadratic models were: y (percent lobedleaf seedlings $)=22.42-4.96(\mathrm{~m})+0.24(\mathrm{~m})^{2}$, $R^{2}=0.85, P=0.0570$ and y (percent lobed-leaf seedlings $)=24.59-4.79(\mathrm{~m})+0.22(\mathrm{~m})^{2}, R^{2}=$ $0.97, P=0.0062$ for pollinator movement east and west, respectively.

seedlings. Pollen flow between the east and west row sections for row 10 was similar. For the east section of row $10,2.9 \%$ and $1.6 \%$ lobed-leaf seedlings were determined at $3 \mathrm{~m}$ and $6 \mathrm{~m}$ from the donor plant center (or $\approx 1 \mathrm{~m}$ and $4 \mathrm{~m}$ from the donor plot edge), respectively, with no lobed-leaf seedlings detected further down the row (Fig. 2). Similarly, for the west portion of row $10,9.9 \%$ and $2.8 \%$ lobed-leaf seedlings were found $3 \mathrm{~m}$ and $6 \mathrm{~m}$ from the center of donor plants (or $\approx 1 \mathrm{~m}$ and $4 \mathrm{~m}$ from the edge of the donor plants), respectively, with few lobed-leaf seedlings ( $1.3 \%$ or less) detected further down the row. Quadratic regression models best described the relationship between distance from the donor plant center and the decrease in the percentage of lobed-leaf seedlings for both the east and west sections of row 10. Regardless of direction, after $\approx 4 \mathrm{~m}$ from the edge of the donor plant border, pollen flow was significantly reduced for row 10 .

Pollinator movements across rows were similar $(P>0.05)$ between the south and north field sections from the donor plot area. At the center of the donor plot area, the percentage of lobed-leaf seedlings was $\approx 39 \%$. However, $\approx 3 \mathrm{~m}$ from the center of the donor plants (or $\approx 0.5 \mathrm{~m}$ from the donor plot edge), the percentage of lobed-leaf seedlings was $7.5 \%$ and $10.0 \%$ across rows for the north and south sections of the field, respectively; whereas further across the rows, 3.5\% and $3.6 \%$ of lobed-leaf seedlings were observed $\approx 6 \mathrm{~m}$ from the donor plant center (or $4.5 \mathrm{~m}$ from the donor plot edge) for the north and south sections of the field, respectively (Fig. 3). At $9 \mathrm{~m}$ from the donor plant center (or $7.5 \mathrm{~m}$ from the edge of donor plants) across rows, $\approx 0.9 \%$ and $1.8 \%$ lobedleaf seedlings were detected for the north and south sections, respectively. Beyond this 7.5-m area from the donor plot edge, little pollen movement was observed regardless of the direction across rows. A quadratic relation- 


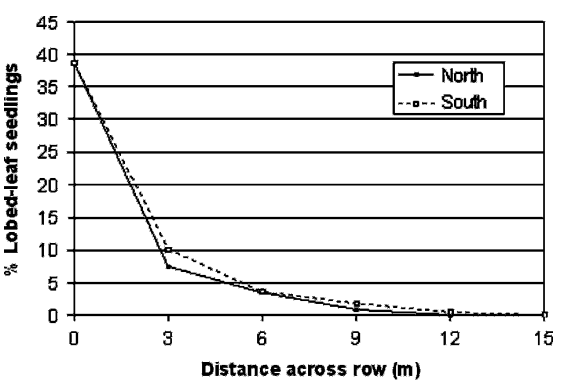

Fig. 3. The percentage of lobed-leaf watermelon seedlings as a function of distance across the row combined for 2001 and 2002. Sampling was done on a transect located at the center of row 10 and extended across rows both north and south. Quadratic models best described pollinator movements (percent lobed-leaf seedlings) both north $(0 \mathrm{~m}$ to $15 \mathrm{~m})$ and south $(0 \mathrm{~m}$ to $15 \mathrm{~m}$ ) across rows with distance from the center of row 10 that went through the middle of the 'Crimson Sweet' donor plant area. Quadratic models were: y (percent lobed-leaf seedlings $)=34.11-7.10(\mathrm{~m})+0.33(\mathrm{~m})^{2}, R^{2}=$ $0.90, P=0.0342$ and y (percent lobed-leaf seedlings $)=34.77-6.96(\mathrm{~m})+0.32(\mathrm{~m})^{2}, R^{2}=$ $0.92, P=0.0229$ for pollinator movement north and south, respectively.

ship best described the decrease in the percentage of lobed-leaf seedlings with distance from the donor 'Crimson Sweet' plants across both north and south field sections. Regardless of the direction across rows, little pollen movement was observed beyond this 4.5- $\mathrm{m}$ area from the edge of the donor plots.

Across-row (north and south) pollinator movements did not differ from those occurring east or west down the row from the donor plot center on row 10 (Fig. 1) based on the Wilcoxon signed rank test for paired comparisons of separate analysis of north versus east, north versus west, south versus east, and south versus west. Regardless of the direction from the donor plant area, the percentage of lobed-leaf seedlings decreased rapidly into the recipient 'Sunshade' watermelon plants (Figs. 2 and 3).

\section{Discussion}

This study indicated that the evaluation of pollen flow provided a definite directionality to pollinator movement and gene migration in watermelon. Although we detected pollinator movement that was strongly directional in both directions (east and west) down the row from the central block of $\mathrm{Nl}$ donor plants, results also indicate that significant movement also occurred across rows in both directions (north and south) from the donor plot. Pollinators usually move to the closest adjacent inflorescence (Handel, 1982; Levin et al., 1971; Waddington, 1981; Zimmerman, 1979) with between-plant movements occurring primarily to the first or second closest neighboring flower (Collevatti et al., 2000). However, the directionality of pollinator foraging movements can change in response to flower orientation (Collevatti, 1998; Ginsberg, 1986), plant density (Handel, 1983; Manasse,
1992; Morris, 1993), prevailing wind direction (Dag and Eisikowitch, 1995), and the occurrence of other pollinators (Stanghellini et al., 2002). As indicated by our study, a pollinator can easily move across rows if the next closest flower is in that direction instead of down the row. Reduced linear directionality of pollinator movements (or less downthe-row movements) can occur when flowers are available to pollinators in two dimensions (Pyke, 1978).

Most pollen is deposited on the nearest neighboring flower from where pollen was collected (Cresswell et al., 1995). However, pollen from any one flower is not always completely deposited on the next flower visited (Thomson and Plowright, 1980; Waser and Price, 1982). Significant amounts of pollen carryover most likely occurred in this study because pollen flow was detected in most directions and became diluted as distance from the donor block increased. The low-frequency scattering of lobed-leaf seedlings on rows at considerable distances (greater than $10 \mathrm{~m}$ ) from the donor block (Figs. 2 and 3) indicates that pollen carryover may have occurred multiple times by pollinators to reach this significant distance, inhive pollen transfer between honeybees may have resulted, or that pollinators transported pollen long distances. Handel (1982) found that flights between muskmelon plants by bumble bees were generally short, with $\approx 60 \%$ of flights occurring to the nearest neighboring flower 0.5 to $1 \mathrm{~m}$ away, $\approx 40 \%$ to flowers 1 to $3 \mathrm{~m}$ away, and only $0.9 \%$ of flights were longer than $3 \mathrm{~m}$; furthermore, the short flight distances by bumble bees and the nonsymmetrical movement of muskmelon pollen indicated that a significant amount of pollen carryover occurred. Long pollinator flights from the 'Crimson Sweet' donor plants or 'Sunshade' flowers containing carryover pollen could result in the longdistance movement of the $\mathrm{Nl}$ gene; but, the low-frequency detection of this gene at distances greater than $4 \mathrm{~m}$ from the donor block was most likely the result of pollen carryover, because the typical flight distance of pollinators is less than $3 \mathrm{~m}$ and higher gene frequencies would be expected for longdistance movement because the pollinator is carrying and depositing pollen collected directly from the donor block.

Results from our study also corroborate many others' findings (Handel, 1982, 1983; Handel and Mishkin, 1984; Hokanson et al., 1997a, 1997b) that cucurbit pollen is generally carried only a short distance from the donor plant, although small amounts are often deposited in an asymmetrical pattern several meters from these plants. Handel (1982) indicated that gene flow for Cucumis melo can still be relatively high at $7 \mathrm{~m}$ from the donor plants and that some pollen probably travels even further. However, the migration of genes within plant populations is often only a few meters per year, even when there are no physical barriers to prevent longer flights by insects (Handel, 1983). Gene frequencies in natural cucurbit plant populations probably experience similar shifts depending on the available pollinators or the pollinators' foraging patterns.

In summary, this study indicates that although significant amounts of linear pollinator movements occur down the row, pollinator movements in watermelon are not as simple as just maintaining a linear direction straight down the row, but are related to the short flight distances that most likely occur to the closest neighboring flower from the one that was previously visited. Because watermelon vines grow out in multiple directions, including across rows, a pollinator can easily move across rows if the next closest flower is in that direction instead of down the row. This study further demonstrates the importance of flight directionality by honeybee, bumble bee, and other bee pollinators, which has a direct effect on foraging efficiency and gene flow in cucurbit populations.

\section{Literature Cited}

Collevatti, R.G. 1998. Pollination ecology of the tropical weed Triumfetta semitriloba Jacq. (Tiliaceae), in south-eastern Brazil. Rev. Bras. Biol. 58:383-392.

Collevatti, R.G., J.H. Schoereder, and L.A.O. Campos. 2000. Foraging behavior of bee pollinators on the tropical weed Triumfetta semitriloba: Flight distance and directionality. Rev. Bras. Biol. 60:29-37.

Cresswell, J.E., A.P. Bassom, S.A. Bell, S.J. Collins, and T.B. Kelley. 1995. Predicted pollen dispersal by honey-bees and three species of bumble-bees foraging on oil seed rape: A comparison of three models. Funct. Ecol. 9:829-841.

Dag, A. and D. Eisikowitch. 1995. The influence of hive location on honeybee foraging activity and fruit set in melons grown in plastic greenhouses. Apidologie (Celle) 26:511-519.

Delaplane, K.S. and D.F. Mayer. 2000. Crop pollination by bees. CAB Intl., Wallingford, UK.

Foster, R., D. Egel, E. Maynard, R. Weinzierl, M. Babadoost, H. Taber, L. Jett, and B. Hutchison. 2002. Midwest vegetable production guide for commercial growers 2002. Univ. Ill. Ext. Bul. C1373-02.

Foster, R., R. Latin, D. Egel, E. Maynard, R Weinzierl, M. Babadoost, H. Taber, L. Jett, and B. Hutchison. 2001. Midwest vegetable production guide for commercial growers 2001. Univ. IL. Ext. Bul. C1373-01.

Free, J.B. 1993. Insect pollination of crops. 2nd Ed. Academic Press, London, UK.

Ginsberg, H. 1986. Honey bee orientation behavior and the influence of flower distribution on foraging movements. Ecol. Entomol. 11: 173-179.

Hails, R.S. 2000. Genetically modified plants: The debate continues. Trends Ecol. Evol. 15:14-18.

Handel, S.N. 1982. Dynamics of gene flow in an experimental population of Cucumis melo (Cucurbitaceae). Amer. J. Bot. 69:1538-1546.

Handel, S.N. 1983. Contrasting gene flow patterns and genetic subdivision in adjacent populations of Cucumis sativus (Cucurbitaceae). Evolution 37:760-771.

Handel, S.N. and J.L.V. Mishkin. 1984. Temporal shifts in gene flow and seed set: Evidence from an experimental population of Cucumis sativus. Evolution 38:1350-1357.

Hokanson, S.C., R. Grumet, and J.F. Hancock. 1997a. Effect of border rows and trap/donor 
ratios on pollen-mediated gene movement. Ecol. Appl. 7:1075-1081.

Hokanson, S.C., J.F. Hancock, and R. Grumet. 1997b. Direct comparison of pollen-mediated movement of native and engineered genes. Euphytica 96:396-403.

Kirkpatrick, K.J. and H.D. Wilson. 1988. Interspecific gene flow in Cucurbita: C. texana vs. C. pepo. Amer. J. Bot. 75:519-527.

Levin, D.A., H.W. Kerster, and M. Niedzlek. 1971. Pollinator flight directionality and its effect on pollen flow. Evolution 25:113-118.

Manasse, R. 1992. Ecological risks of transgenic plants: Effects of spatial dispersion on gene flow. Ecol. Appl. 2:431-438.

Maynard, D.N. and G.J. Hochmuth. 1997. Knott's handbook for vegetable growers. 4th Ed. John Wiley \& Sons, Inc., New York, NY.

McGregor, S.E. 1976. Insect pollination of cultivated crops. U.S. Dept. Agr.-Agr. Res. Serv. Agr. Hdbk. 496.

Mohr, H.C. 1953. A mutant leaf form in watermelon. Proc. Assn. S. Agr. Workers 50:129130.
Morris, W.F. 1993. Predicting the consequence of plant spacing and biased movement for pollen dispersal by honey bees. Ecology 74: 493-500.

Pyke, G.H. 1978. Optimal foraging: Movement patterns of bumblebees between inflorescences. Theor. Popul. Biol. 13:72-98.

Robinson, R.W. and D.S. Decker-Walters. 1997. Cucurbits. CAB Intl., Wallingford, UK.

Rogers, H.J. and H.C. Parkes. 1995. Transgenic plants and the environment. J. Expt. Bot. 46: 467-488.

Silberbauer, L., M. Yee, A. Del Socorro, S Wratten, P. Gregg, and M. Bowie. 2004. Pollen grains as markers to track the movements of generalist predatory insects in agroecosystems. Intl. J. Pest Mgt. 50:165-171.

Stanghellini, M.S., J.R. Schultheis, and J.T. Ambrose. 2002. Pollen mobilization in selected cucurbitaceae and the putative effects on pollinator abundance on pollen depletion rates. J. Amer. Soc. Hort. Sci. 127:729-736.

Thomson, J.D. and R.C. Plowright. 1980. Pollen carry over, nectar rewards, and pollinator behavior with special reference to Diervilla lonicera. Oecologia 46:68-74.

Umbeck, P.F., K.A. Barton, E.V. Nordheim, J.C. McCarty, W.L. Parrott, and J.N. Jenkins. 1991. Degree of pollen dispersal by insects from a field of genetically engineered cotton. J. Econ. Entomol. 84:1943-1950.

Waddington, K.D. 1981. Factors influencing pollen flow in bumble bee-pollinated Delphinium virescens. Okios 37:153-159.

Waser, N.M. 1991. Population structure, optimal outbreeding, and assertive mating in angiosperms. In: Thornhill, N.W. (ed.). The natural history of inbreeding and outbreeding: Theoretical and empirical perspectives. Univ. Chicago Press, Chicago, IL.

Waser, N.M. and M.V. Price. 1982. A comparison of pollen and fluorescent dye carry-over by natural pollinators of Ipomopsis aggregata (Polemoniaceae). Ecology 63:11681172.

Zimmerman, M. 1979. Optimal foraging: A case for random movement. Oecologia 43:261267. 